一般研究発表予稿集

$1 \mathrm{X}$ 線エネルギーの効果を考慮した低コントラスト分解能評価用 寒天ファントム

JA愛知厚生連加茂病院 深田鿓司, 江藤貴樹

豊田地域医療センター 柴田和宏

藤田保健衛生大学病院 \#田義宏，吉見 聡，片岡由美，中井敏昭 藤田保健衛生大学・衛生学部 辻岡勝美, 加藤大樹

【目的】CT装置において, 低コントラスト分解能の評価は重要な項目 である. しかし, 現状での低コントラスト分解能の評価ではファン トムの材質とX線の線質についての検討は行われていない. 実際, それらの関係によりCT值は大きく変化し, 低コントラスト分解能も 変化するものと予想される，われわれは，X線の線質と物質の素 材，そして，それによる低コントラスト分解能を検討するため, 新 型のファントムを作成した.

【方法】実際の患者の組成について, 非造影時については, 砂糖(しょ 糖)水の濃度を調整した，造影時については，希釈造影剤の濃度を調 整した．それぞれの溶液は寒天を用いて固化しファントムとした。 ファントムは円錐形のものと, 中央に微小なX線吸収差を持たせた 円筒形のものを作った. 円錐形のファントムでは管電圧, 被写体の 大きさ, 組成によるCT值の変動を調べた. 円筒形のものでは低コン トラスト分解能を視覚的に調査した. また, SNR值による低コント ラスト分解能の数值比較も行った。

【結果】円錐形のファントムでは, 管電圧, 被写体の大きさ, 組成に よりCT值が変化することが確認できた。 特に, 砂糖水と希釈造影片 とではCT值の変化の程度が大きく異なった. 円筒形のファントムで は砂糖水と希釈造影剤では, 同一のスキャン条件でも低コントラス 卜分解能は変化した.

【考察】従来の低コントラスト分解能評価用ファントムは「エネルギー 依存性がない」とが目的とされており, 造影剤注入を行う臨床とは 異なるものと考える. 今回われわれは, 実際の臨床を想定して, 非 造影時, 造影時に対応したファントムを作成, 検討した。このよう なファントムにより, 実際の臨床で役立つ低コントラスト分解能評 価が行えるものと考える.

2 8DASマルチスライスCTでの低コントラスト分解能に与えるへ リカルピッチの影響

大阪市立総合医療センター・中央放射線部 福西康修、池田茂信

久島曷巳, 廣瀬雅彦, 伊泉哲雄, 畑中一男

大阪市立住吉市民病院・放射線科 寺川彰一

【目的】2002年 3 月, 当センターに8DASマルチスライスCTが導入さ れた。従来装置とは異なる多チャンネルでの収集, またFeldkamp法 を用いた再構成法がこの装置の特徴である。 そこで通常の検查に用 いる撮影パラメータの検証を目的として, 特に低コントラスト分解 能に与えるへリカルピッチの影響について検討を行ったので報告す る.

【方法】CT装置は東芝社製Aquilion/M8を用いた。肝臟とその内部の low density massをシミュレーションしたHelical CT Phantom(CIRS) を対象とし $0.5 \mathrm{~mm} \times 8$ row, $1 \mathrm{~mm} \times 8$ row, $2 \mathrm{~mm} \times 8$ row, $3 \mathrm{~mm} \times 8$ row, $4 \mathrm{~mm} \times 8$ rowでそれぞれHelical pitch5, 7，9，10，11，13の撮影を行っ た. axial imageは $5 \mathrm{~mm}$ および $10 \mathrm{~mm}$ thickness, MPR画像は $5 \mathrm{~mm}$ thicknessの画像を作成し, SNR・プロファイルカーブ・視覚での評 洒を行った。

【結果】5mmおよび10mm thicknessのAxial imageにおいて, low density massの形状が $6.3 \mathrm{~mm} \phi$ の球体とスライス面と直交方向にのびる $10 \mathrm{~mm} \phi \times 15 \mathrm{~mm}$ 円柱では評価が多少異なるが, thin slice, low pitch収 集画像でSNRが高くなった. High pitchでは10前後の值がよいと思わ れた. Total scan timeを同一にして比較した場合, axial imageでは厚 いスライスでhigh pitchであることが優位であったがアーチファクト
は增加し, MPR画像では小直径のlow density massの描出がslice thicknessの増加によって明らかに低下した。

【結論】多チャンネル化によるthin slice, High pitchでの撮影の優位性 が低コントラスト分解能で確認された。 また今後，より多列化・高 速化が進むであろうマルチスライスCTにおいて多用されると考えら れるMPR画像においても thin sliceでかつ短時間の収集は必須である と思われた。

\section{8DASマルチスライスCTでの低コントラスト分解能に与える再 構成関数の影響}

大阪市立総合医療センター・中央放射線部 伊泉哲雄，池田茂信 久島昌巳，廣瀬雅彦、福西康修、畑中一男 大阪市立住吉市民病院・放射線科 寺川彰一

【目的】2002年 3 月, 当センターに8DASマルチスライスCTが導入さ れた，従来装置とは異なる多チャンネルでの収集，またFeldkamp法 を用いた再構成法がこの装置の特徵である。そこで低コントラスト 分解能に与える再構成関数の影響について検討を行ったので報告す る.

【方法】CT装置は東芝社製Aquilion/M8を用いた，肝臟とその内部の low density massをシミュレーションしたHelical CT Phantom(CIRS) を対象とし, conventional scan, $2 \mathrm{~mm} \times 4$ row (HP3.5, 5), $2 \mathrm{~mm} \times 8$ row （HP7，10）で撮影を行った。また位置依存性を調べるためにscan area 中央と周囲で同様な撮影を行った，axial imageは $5 \mathrm{~mm}$ おび゙10 mm thickness (ただしconventional scanは4mm, 8mm thickness)，MPR画像 は5mm thicknessの画像を作成し, SNR・プロファイルカーブ・視覚 での評価を行った.

【結果】5mmおよび10mm thicknessのAxial imageにおいて, low density massの形状が $6.3 \mathrm{~mm} \phi$ の球体とスライス面と直交方向にのびる $10 \mathrm{~mm}$ $\phi \times 15 \mathrm{~mm}$ 円柱では評価が異なった. 従来の再構成法であるMUSCOT 再構成では周囲の低コントラスト分解能は $6.3 \mathrm{~mm} \phi$ の球体では上昇し たが8DASから採用されたTCOT再構成では低下した。また $10 \mathrm{~mm} \phi \times 15 \mathrm{~mm}$ 円柱では両再構成法とも周囲での低コントラスト分解 能は低下した. 傾向として, $6.3 \mathrm{~mm} \phi$ の球体では中央のSNRは再構成 法の影響を受けないが, 周囲ではMUSCOT再構成でhelical pitchとと もにSNRが大きく変化した.

【結論】8DAS以降の多列マルチスライスCTでは再構成時にコーン角 を考慮したFeldkamp再構成法の必要性が唱えられている. 今回の低 コントラスト分解能の結果はすべて実効スライス厚の位置依存性が 影響した結果と考えられた. helical pitchおよびscan area内の位置に 影響を受けにくいFeldkamp再構成法の有用性が検証された結果と考 えられた。

4 二值化操作を用いない新しいヘリカルアーチファクト評価 藤田保健衛生大学・衛生学部 辻岡勝美 藤田保健衛生大学 · 衛生学部(学生会員) 秋野成臣，加藤大樹 藤田保健衛生大学病院 井田義宏, 中井敏昭 市立四日市病院 高橋康方, 丹羽正厳

【目的】ヘリカルスキャンによる画像劣化要因としてスライス感度プ ロフィール $(\mathrm{SSPz})$ の変化と風車状アーチファクトがある．われわれ はこれら画像劣化要因の評価のための総合的な評価方法が必要と考 えた，従来，このようなアーチファクトの評価を行う場合，しきい 值設定により画像の二值化を行い, その形状, 面積などが利用され てきた. 今回われわれは，二值化操作を用いない新しいアーチファ クト評洒法を考案した.

【方法】本法は画像のCT值情報を含んだ評価法である。その手法は,

（1）アルミ製ロートを寝台に取り付けヘリカルスキャンを行う。（2）

ロート全体を含むようにROIを設け，ヒストグラムを求める。 